DOI https://doi.org/10.18551/rjoas.2018-09.36

\title{
STUDY OF APPLICATION OF TRADING HOUSE AS A MARKETING INSTITUTION OF AGRICULTURAL PRODUCTS IN EAST JAVA, INDONESIA
}

\author{
Wisnujati Nugrahini Susantinah*, Koesriwulandari, Yudho Dwie Prasetyo \\ *E-mail: wisnujatinugrahini@gmail.com
}

\begin{abstract}
Trading House is an institution formed by the Government with the aim of helping farmers in the implementation of marketing their products. In Indonesia, the majority of farmers are still marketing their products to middlemen, this is because farmers have previously borrowed funds for their daily needs, so they have to sell products to middlemen with prices determined by the middlemen. In this research, the role of Trading House institutions to provide efficient and effective marketing solutions like farmers is to be studied. The research was conducted in Sidoarjo, East Java, Indonesia by using descriptive analysis.
\end{abstract}

\section{KEY WORDS}

Trading house, agriculture, marketing, public service.

Farmers in Indonesia on average still depend on middlemen, and this cooperation habit is valid until now, this cooperation actually disadvantages farmers, but there is no other choice for farmers because farmers are used to borrowing funds for life the day before the harvest arrives. In the world arena, the Government of Indonesia has signed an ASEAN agreement, while the agreement is that ASEAN will become a production base in the world which certainly has an impact on farmers' demands, farmers must increase production, quality productivity and increase the ability to transact with global markets Small farmers with a narrow land area, low education and weak mastery of technology need to be given assistance by the government, because farmers are not used to trade in a modern way. So the Government needs to help farmers in the process of marketing results. In the World, known as the Trading house, Bunge, Cargill and Dreyfus and Archer Daniels Midland, these four institutions are important for world food trade, by working using silo networks (places for storing large quantities of grain), ports, ships and farmers who are difficult to imitate, there is a Mayhem trading house in power in the agricultural market between 2010 and 2012, in that year the prices of corn and soybeans soared due to drought in the US and Brazil. While wheat prices surged after Moscow imposed a ban on cereal exports because of a panic caused by heat waves in Russian territory. (Meyer, Gregory, 2013) Farmers who only have the ability to grow crops, it is necessary for the Government to provide assistance to farmers by forming institutions that are able to help marketing farmers' products.

Formulation of the problem:What is the role of Trading House in East Java Province of Indonesia in marketing agricultural products, What is the Role of the Provincial Government in managing the Trading House in East Java Province.

Research purposes, To analyze the role of Trading House in East Java Province in marketing agricultural products, Analyzing the Role of the Provincial Government in managing the Trading House in East Java Province.

\section{METHODS OF RESEARCH}

The research location was chosen intentionally (purposive) in East Java Province precisely in Sidoarjo Regency because Sidoarjo Regency was a district with relatively high rice production in East Java., Sample Determination Method Indetermining, the sample in this study by using purposive sampling method to experts such as agricultural experts from the East Java Agriculture Service, agricultural extension experts, Sidoarjo Regency Agriculture Office and Development Planners (BAPPEDA)., Data Retrieval Method, For the sake of more in-depth data retrieval, it is necessary to use the Delpi technique where the questionnaire is repeated repeatedly to experts and farmers by interviewing the list of 
questions that have been prepared, and Focus Group Discusion (FGD). Types of Data, The data collected is primary data and secondary data. To explore data about the initial ability to use primary data collection methods carried out through interviews directly with respondents, the tools used were questionnaires, secondary data was obtained from statistical data of research areas and related institutions (Food Security Office, Agriculture Office and BPS Sidoarjo Regency)., Data Analysis Method, Using Delphi analysis and expected to determine the strategy of agricultural development through increasing the role of Trading house institutions in East Java Province.

\section{RESULT OF STUDY}

Analysis of the role of Trading House in Sidoarjo Regency, East Java Province In the analysis of the Role of Trading Houses in Sidoarjo Regency, it is necessary to pay attention to several characteristics that must be owned by the Trading House:

1. Building a system of division of labor, at the grass-root economy, the people of the economy are free to produce according to their expertise, producing superior commodities on a larger scale to be traded, by handling various kinds of community commodities, so that efficient and directed. In Japan, for example, it can create a large agricultural area, people who are members of the cooperative movement or local farmer groups cultivate certain commodities simultaneously and together. In addition to forming economies of scale, such handling also allows the fulfillment of the need for seeds, fertilizers and even anti-pest treatment with agricultural mechanization that is relatively cheaper for each hectare.

The results show that there is no system established at the sub-district level, so far farmers sell their products to middlemen or to the puspa Agro market, and are bought by buyers from other regions, the majority of farmers still think that the market is a meeting place for sellers and buyers, farmers sell products selling pedestrian products that have been prepared by Puspa Agro managers, so that the vast Puspa Agro in Jemundo becomes less optimal to operate because farmers still sell individually not in groups.

In Puspa Agro the product is marketed according to zoning or region to make it easier for buyers to buy products.

Table 1 - Product Marketing Zoning in Puspa Agro Jemundo Sidoarjo

\begin{tabular}{|l|l|}
\hline No & Product marketing zone \\
\hline 1 & Prosecced Product \\
\hline 2 & Meal and Fish \\
\hline 3 & Flower \\
\hline 4 & Vegetable \\
\hline 5 & Various Fruit \\
\hline 6 & Crop, Rice \\
\hline
\end{tabular}

Source: Puspa Agro 2018.

Table 2 - Commodities Offered By Trading House To Buyers

\begin{tabular}{|l|l|}
\hline No & The commodities offered by Puspa Agro \\
\hline 1 & Corn \\
\hline 2 & Coffee \\
\hline 3 & Rice \\
\hline 4 & Fish \\
\hline 5 & Chocolate \\
\hline 6 & Chili \\
\hline 7 & Coconuts \\
\hline
\end{tabular}

Source: Puspa Agro 2018.

There are six (6) zones provided, the area of each zoning is quite broad, it's just that the zones are not optimized, there are only a few sellers and few buyers, this is due to several reasons, namely the entrance to Puspa Agro's parent market is relatively narrow and traffic jams, making buyers reluctant to shop at Puspa Agro. The strength of Puspa Agro as a business center because of its location in the wide main market, adequate parking, and a 
special place for disposal of coconut fiber. Moreover, for the needs of loading and unloading, containers or truck transporting coconut can directly enter the market building.

The commodities offered by Puspa Agro are diverse, such as corn, coffee, rice, chili, fish, chocolate, vegetables and coconut. This shows the potential for good product diversity, but it is necessary to increase the volume of availability, because the need for export is very large, which has been in East Java and throughout Indonesia, the product volume is still relatively small. The area is also spread inefficiently for transportation costs. There are still many agricultural products that can be optimized, such as pumpkin, onion and cinnamon. Whereas East Java is potential for fruits, vegetables and others. Pumpkin potential in planting in Banyuwangi needs to be increased. Shallots and cinnamon potential to be planted in Malang, East Java can still be increased in production, but this does require support from government policy.

Table 3 - Transactions From Trading Houses in Sidoarjo Regency

\begin{tabular}{|l|l|l|}
\hline No & Product & Transaction Value (Rupiah) \\
\hline 1 & Yelow Squash & 3.000 .000 .000 \\
\hline 2 & Onion & 3.000 .0000 .000 \\
\hline 3 & Cinamon & 2.800 .000 .0000 \\
\hline
\end{tabular}

Source: Puspa Agro in 2018.

In the table above, the turnover obtained has indeed increased, meaning that the Trading house division is more profitable because the broader market does not only serve domestically. In the Transaction from Pumpkin, Red Onion and Cinnamon and in 2017 the commodity Coconut.

Table 4 - Increase in Trading House Turnover

\begin{tabular}{|l|l|l|}
\hline No & Year & Omset (Milliart Rupiah) \\
\hline 1 & 2014 & 14,37 \\
\hline 2 & 2015 & 78 \\
\hline 3 & 2016 & 279,12 \\
\hline 4 & 2017 & 451,22 \\
\hline
\end{tabular}

Source: Puspa Agro 2018.

At the Trading House Division, it seeks to accelerate the uptake of harvests of farmers, farmers, as well as farmers or fishermen, the first year of operation of the Trading House, namely in mid-2014 its turnover is only Rp. 14.37 billion. 2015 rose to Rp. 78 billion. The surge in turnover occurred in 2016, which was recorded at Rp 279.12 billion, and for 2017 until October the turnover of Trading House reached Rp 451.22 billion.

2. The second concept is the Trading house in charge of organizing community activities into (1). Production and development of community superior commodities, (2). Marketing and distribution channels, and (3). Financial management with a savings and loan program... The results of the study indicate that Trading House in Jemundo, Sidoarjo Regency is still only able to receive products from farmers and cooperation with other parties to develop certain products. Puspa Agro collaborates with PT Mitra Mina Agro (MMA) to develop a coconut business specifically to meet export markets, in addition to semi hushed coconut, it will also export white copra and white meat. Both of these products are also projected for the export markets of India, Thailand, Sri Lanka, China, Dubai, India and the United States (US). At the Puspa Agro location will also operate a greated coconut plant (grated coconut) with the aim of exporting to Canada, the US, and several countries in Europe.

In the local market, the distribution of coconut from Puspa Agro is widely channeled to the markets of Surabaya and Sidoarjo as well as some areas in East Java, such as Gresik, Babat (Lamongan), Tuban, Bojonegoro, Mojosari (Mojokerto), Pare (Kediri), Kertosono. In fact, from Puspa Agro coconut also distributed to Jatirogo (Cepu), Solo, and Yogyakarta.

3 . The third concept is Encouraging the formation of economies of scale in the field of production, distribution channels and community savings and loans, so that the application 
of modern technology and management, from the results of research shows that business people attend an auction held on Tuesday (10/24/2017), transactions occur Rp. 17.525 billion. There were 13 transactions, followed by participants from both farmers and agro businessmen in East Java and several regions in Indonesia. In September 2017 there were transactions worth Rp 5.9 billion, which means an increase in transactions of 11,625 billion.

From the transaction of Rp. 17.525 billion, the yellow pumpkin commodity was ranked first with a value of Rp. 3.5 billion which was collected from 1,000 tons. The second position is occupied by commodities of shallot plant seeds, which are transacted at a value of Rp. 3 billion from a total volume of 200 tons, followed by a commodity of cinnamon weighing 80 tons with a transaction value of Rp. 2.88 billion. dried turmeric, honey pineapple, brown sugar (local). In addition, the commodities are candlenut, arabica coffee, cardamom, mahogany, dried kahe, and corn.

Encouraging the formation of economic problems, it is only that Trading House facilitates transactions in the main Market area, there is no system built to improve greater economic performance and there is no savings and loan assistance activity.

4. Each region has a special commodity which is due to climate differences between regions. Likewise with existing handicrafts and home industries (cottage industries) due to cultural influences that have been growing for generations. From the results of the research this concept is still an obstacle, because farmers still work alone and there is no large-scale production.

5. Combining several villages in one sub-district, Trading house assists the development of the people's economy, coordinates other components to build supporting forces. Bringing together the components of production, consumption (and distribution) and funds will build the strong participation of the people needed to drive the people's economic progress.

Puspa Agro as a Trading House in East Java has indeed been able to export semihushed coconut coconut on March 13, 2018, to Toronto, Canada. The export was carried out by sending one 40 feet container (about 26.5 tons). Besides Canada, the plan, semi hushed coconut is also exported to Thailand, China, Dubai, Pakistan and India.

Coconut commodity turns out to be a profitable commodity for sale. Coconut is obtained from many areas in East Java such as Banyuwangi, Lumajang, Jember, and Trenggalek, from outside East Java, it comes from Pangandaran, Central Java, Sulawesi Island, such as Luwuk, Toli-toli, Palu, Gorontalo, but there is no economic development of the people who are able coordinate production, distribution and funding.

6. Distribution activities deal with meeting the daily needs of the community by maximizing the role of the organization, channeling community superior commodities to the market as well as meeting the needs of the community related to national supply

7. Work systemically in a structured organization, the organization consists of nodes that work interdependently implementing strict SOP (Standard Operating Procedure). Each node acts as a Strategic Business Unit (SBU), working independently in accordance with the general policy determined at the central level to be carried out independently by each region. Activity 6.7 has not been implemented because the distribution is still carried out by the community, Trading house is still giving place. Moreover, working systemically by implementing SOPs has not been implemented.

8. Implementing a centralized policy approach, decentralized implementation allows each region to work in accordance with the conditions and progress of their respective regions. Each node is required to manage three main activities: (1). Production and development of community superior commodities, (2). Marketing and distribution channels, and (3). Financial management with savings and loan programs. Especially for financial management applies centralized policies that are supervised by applying the Management Information System (MIS) designed for it. Computer use and ICT (Information and Communication Technology) From the results of the study showed that in carrying out its duties PT Puspa Agro in collaboration with East Java Disperindag tried to improve its economic role by continuing to increase the number of bidders, both from farmers / farmer groups and agro sector businessmen, in hopes of boosting the added value of farmers, farmers, and fish farmers / fishermen, especially in East Java. The auction mechanism is a 
means of trading various agricultural commodities, effective to help the owners of goods (farmers / Gapoktan) and prospective buyers (buyers), accelerate the sale of goods with large volumes and fair prices. While for potential buyers, this auction forum is a quick way to get good quality goods and relatively cheap prices. Implementation of Management Information System (MIS) and the use of computers and ICT (Information and Communication Technology) is still not optimal.

Analysis of the Role of the Provincial Government in managing the Trading House in the Province East Java The East Java Provincial Government handed over the management of Trading House to the Jatim Graha Utama Limited Company (PT) in the hope of managing the Trading House profitably. Jatim Company Graha Utama stated that the management of Trading House is constrained by operational costs and costs to provide credit to farmers, because the Trading House concept is one of them providing capital assistance to farmers. The problem experienced by PT Jatim Graha Utama is the reluctance of farmers to form farmer groups, because all this time the operations carried out by the Trading House are farmer groups, not individual farmers, this has an impact on the number of products offered by farmers, on the other hand buyers ask for agricultural products in quantities large and sustainable. The availability of agricultural products is also caused by the absence of agricultural product clusters in East Java, so when there is a demand for agricultural products cannot be fulfilled because the products requested are sporadic and relatively small in production. Not yet optimal in the implementation of evaluation and monitoring in the implementation of Trading House management in Jatim Graha Utama Limited Company (PT), this will cause the marketing of products to become less smooth.

\section{CONCLUSION}

The role of Trading House is still not optimal, because it does not have a system that is able to become a reference for building a system of division of labor, at the sub-district level, organizing community activities into (1). Production and development of community superior commodities, (2). Marketing and distribution channels, and (3). Financial management with savings and loan programs.

The East Java Provincial Government handed over the management of Trading House to the East Java Graha Utama Limited Company (PT) byBUMD.

\section{REFERENCES}

1. Abdul Basit, Tampuli Abukari, Ouml Ztornaci Burak, and Veziroğlu P uuml ren. 2016. -Total Factor Productivity Growth of Turkish Agricultural Sector from 2000 to 2014: Data Envelopment Malmquist Analysis Productivity Index and Growth Accounting Approach.II Journal of Development and Agricultural Economics 8(2): 27-38.

2. Achmad, Suryana dan Kariyasa, Ketut, -Ekonomi Padi Di Asia: Suatu Tinjauan Berbasis Kajian Komparatifll akses 3 september 2015, http://pse.litbang.pertanian.go.id/

3. Acosta, Lilibeth A, Kagatsume, Masaru, ASEAN Rice Sector in the WTO: Analysis of Demand and Supply in a Liberalized Trade Environment, ASEAN Economic Bulletin 20.3 Des 2003, 233-243

4. Akapaiboon, Natta. T, 2010, Trade liberalization, poverty and income distribution in Thailand: A computable general equilibrium-microsimulation analysis, The University of North Carolina at Chapel Hill, ProQuest Dissertations Publishing

5. Arianto, Nugroho Rony, -Tata Ulang Pola Pemasukan Beras Imporll, akses 4 September 2015, http://bisniskeuangan.kompas.com/

6. Baskoro, Arya, Agus Dwi, http://etd.repository.ugm.ac.id/ 5 sept 2015

7. Bayu Krisnamurti,et al, 2014, Ekonomi Perberasan Indonesia, Perhimpunan Ekonomi Pertanian Indonesia (PERHEPI), Samudera Printing Jakarta

8. Boediono, 1981, Ekonomi Internasional, Edisi ke 1, Seri Sinopsis Pengantar IImu Ekonomi No.3, BPFE, Yogyakarta

9. BAPPEDA. 2013. -Kabupaten Sidoarjo.ll: 1-6.

10. Electronic Source: http://bappeda.jatimprov.go.id/ 